Acta medico-historica Rigensia (1999) IV: 443-444

DOI: 10.25143/amhr.1999. IV.34

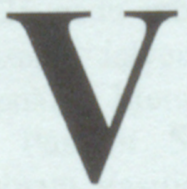



Arnis Vīksna

\section{VĒRTĪGS RĀDĪTĀJS}

Inženierzinātnu doktors Ilgars Grosvalds: Biobibliogrāfija / Sast. J.Kravčinska. Biogrāfiskās apceres autors U. Sedmalis. - Rīga: RTU, 1997. - 72 lpp.

Ne tik bieži ir publicēti medicīnas vēsturnieku biobibliogrāfiski rādītāji (personāls literatūras rādītājs un biogrāfisks apcerējums). Gadsimta pirmā pusē šai jomā daudz pūlējās Izidors Brensons savos pazīstamos ārstu leksikonos, izdoti arī vairāki citi kopkrājumi. Pēckara laikā Maskavā divreiz izdots krājums "Krievijas un PSRS medicinnas vēsturnieki" (1986, 1988), kur ar pamatdarbiem pārstāvēti daudzi Latvijas medicīnas vēsturnieki. Savu literatūras rādītāju 25 gadu jubilejā izdeva Paula Stradina Medicīnas vēstures muzejs, ietverot darbinieku publikāciju sarakstu (1982). Personāli literatūras rādītāji atsevišḳos izdevumos ir publicēti Paulam Stradiņam (1959), Pēterim Gērkem (1974), Konstantinam Vasiljevam (1979, Odesā), Arnim Vīksnam (1992), Jānim Stradiñam (1993) un Imantam Eglītim (1998). Nav nepieciešams īpaši uzsvērt šo rādītāju izziņas un orientācijas nozīmi, jo ikdienā noderīgi tie būs vienmēr.

Dr.ing. Ilgars Grosvalds Latvijas Medicīnas vēsturnieku asociācijā oficiāli iestājās 1993. gadā, bet cieši kontakti ar medicīnas vēsturniekiem viñam izveidojās krietni agrāk, jau no Latvijas Zinātṇu vēstures asociācijas (agrāk - Latvijas Dabaszinātṇu vēsturnieku apvienība) dibināšanas 1958. gadā, bet it īpaši pēc 1975. gada, kad viņš kluva par Latvijas Kīmijas vēstures muzeja līdzdibinātāju un līdz šim laikam ir tā vadītājs. Līdztekus pētījumiem pamatspecialitātē silikātu tehnologijā I. Grosvalds loti daudz veicis Latvijas zinātņu vēstures (tostarp medicīnas un farmācijas vēstures) apguvē, par ko 1994. gadā saṇēma Paula Valdena balvu. 
Rādītājs pieskanots I. Grosvalda dzīves jubilejai (dzimis 1927. gada 21. jūlijā Masačūsetsas pavalstī ASV) un ietver biogrāfisku apceri, publicētus darbus (401 nosaukums) no 1956. līdz 1997. gadam, nepublicētus darbus (23), autorapliecību (1), rediǵētus un recenzētus darbus (15), kā arī literatūru par I. Grosvaldu (43) un personu rādītāju.

Izdevums dod skaidru priekšstatu par I. Grosvalda centieniem medicīnas un farmācijas vēsturē. Viņš publicējis pētijumus par LU Ķīmijas fakultātes Farmācijas nodalu un tās profesoriem Jāni Kupci, Eduardu Zarinuu u.c., kā arī atzinīgi novērtētu pētījumu par latviešu farmaceitiem trimdā. Ietiecoties mikrobiologijas jomā, viņš pētījis Eižena Zemmera darbību un publicējis aprakstus par pasaules zinātnes klasiķiem Luī Pastēru un Robertu Kohu. Cita I. Grosvalda interešu joma ir saistīta ar Kemeru kūrorta vēsturi un pavisam neparasti - par ārstu un izlūku Andreju Peku (nepublicēts palicis apkopojums par citu dēkaini - Sergeju Vronski').

Plašāki I. Grosvalda pētijumi, ietverot arī medicīnu un farmāciju, veltīi Latvijas augstskolu vēsturei, Latvijas un Baltijas zinātniskiem kontaktiem Austrumos un Rietumos, latviešu zinātnieku darbībai trimdā u.c. Tie publicēti vietējos un ārvalstu zinātniskos žurnālos, kongresu un konferenču darbu kopkrājumos vairākās valodās.

Uzteicami, ka, strādājot paralēljomā, I. Grosvalds no sava skatupunkta bagātinājis medicīnas un farmācijas vēstures apguvi.

Rādītājs sastādīts rūpīgi un pamatīgi un kḷūs par teicamu celvedi interesentiem.

\footnotetext{
* Publicēts pēc rādĩtāja iznākšanas: Grosvalds I. Cilvēks - gadsimta leǵgenda jeb Latviešu Minhauzens // Latvijas Ärsts. - 1998. - Nr. 2. - 166.-120.lpp. 